\title{
Factors that matter for financial inclusion: evidence from Peru
}

\author{
Cámara, Noelia \\ Tuesta, David \\ - ReCEIVED: 22 SePteMBER 2014 \\ - ACCEPTED: 9 february 2015
}

\begin{abstract}
This study comprises a quantitative approach to the determinants of financial inclusion in Peru based on micro-data from surveys. Significant correlations are used to identify those socioeconomic characteristics that may affect financial inclusion (or exclusion) of households and enterprises. We incorporate four levels of information: individuals, households, towns, and regions. The results show that the traditionally more vulnerable groups (women, individuals living in rural areas, and young people) are less likely to use the formal financial system. Loans and mortgages appear to be better drivers for financial inclusion than saving products. For enterprises, formality and education stand out as significant factors for financial inclusion. Access to the formal financial system seems to be a problem for households but not for enterprises, and households are also more affected by regional differences.
\end{abstract}

\section{Keywords:}

Financial inclusion, Personal finance, Households, Enterprises.

JEL classification:

D14, G21. 


\title{
Determinantes de la inclusión financiera: el caso de Perú
}

\author{
Cámara, Noelia \\ Tuesta, David
}

\section{Resumen}

Este estudio analiza, con un enfoque cuantitativo, los factores que determinan la inclusión financiera en Perú a partir de microdatos de encuestas. Se utilizan correlaciones significativas para identificar aquellos factores socioeconómicos que pueden afectar a la inclusión financiera (o exclusión) de los hogares y las empresas. Se divide la información en cuatro niveles: individuos, hogares, municipios y regiones. Los resultados muestran que los grupos tradicionalmente más vulnerables (mujeres, individuos que viven en zonas rurales y los jóvenes) son menos propensos a utilizar el sistema financiero formal. Los préstamos y las hipotecas parecen impulsar más la inclusión financiera que los productos de ahorro. Para las empresas, la formalidad y la educación sobresalen como factores significativos para la inclusión financiera. El acceso al sistema financiero formal parece ser un problema para las familias, pero no para las empresas. Además, los hogares se ven más afectados por diferencias regionales.

\section{Palabras clave:}

Inclusión financiera, finanzas personales, hogares, empresas. 


\section{Introduction}

Financial inclusion is a subject of growing interest and one of the major socioeconomic challenges on the agendas of international institutions, policymakers, central banks, financial institutions, and governments. ${ }^{1}$ Financial inclusion is especially important for less developed countries where the interaction between formal financial systems and individuals (households or enterprises) is still low. ${ }^{2}$ Most vulnerable groups find it particularly difficult to access formal financial services, and as a result, they are forced to combine irregular income flows with limited or imperfect financial instruments. Some authors conclude that the lack of use of financial services could lead to a poverty trap and to an increase in the inequality gap (Banerjee and Newman, 1993; Galor and Seira, 1993; Aghion and Bolton, 1997; Beck, Demirgüç-Kunt and Levine, 2007). Empirical evidence suggests that the use of financial instruments increases savings (Aportela, 1999; Ashraf et al., 2010), consumption (Dupas and Robinson, 2009; Ashraf et al., 2010b), and productive investment (Dupas and Robinson, 2009).

The link between banking penetration and poverty sheds light on the importance of financial inclusion. This starts from the premise that households try to maximise their profit, and not their income, with the aim of synchronising income flows and consumption needs. ${ }^{3}$ In this context, financial services are important tools for smoothing consumption cycles. Enterprises, which pursue profit maximisation, can benefit from external capital flows at the appropriate moment, if they have access to credit.

According to the latest World Bank estimates, based on micro-data from surveys, there are still around 2.5 billion people in the world who do not have a bank account. Global Findex (2012) reveals that only around 50\% of adults (people aged 15 and above) in the world have at least one bank account in the formal financial system. However, the percentage of individuals with a bank account varies considerably between developed and developing countries. In developing countries, banking penetration rates are far below the average. In Africa, $20 \%$ of adults have a bank account while in Latin America this figure is 39\%. In Peru only $20.5 \%$ of the adult population has a bank account ${ }^{4}$, a figure far below the $42.2 \%$ in Chile and the more than $55.9 \%$

\footnotetext{
${ }^{1}$ The most recent G20 statement (Saint Petersburg, September 2013) agreed to continue with the financial inclusion agenda and to provide support to countries, politicians and stakeholders to focus efforts on the measurement and monitoring of global progress in terms of access to financial services. In addition, $67 \%$ of banking regulators from a total of I 43 countries promote financial inclusion (Cihak et al., 2012).

${ }^{2}$ After the recent crisis developed countries are also paying more attention to financial inclusion issues to guaranty economic stability. ${ }^{3}$ Most of the existing studies to date are mainly based on macroeconomic data (Patrick, 1996; Beck, et al., 2007; Honohan, 2008; Kendall, Mylenko and Ponce, 2010).

${ }^{4}$ Regarding the distribution of bank accounts, the figures by gender show that the proportion of banked men, out of the total adult population age 15 and above, is higher than the proportion of women, at $23.4 \%$ and $17.6 \%$ respectively. People living in urban areas have a banked rate of $24.4 \%$ and people living in rural areas $13.3 \%$.
} 
in Brazil. Moreover, 5.3\% of the bank accounts in Peru are inactive, meaning that there have not been any deposits or withdrawals in a given month. The problem of involuntary financial exclusion requires intervention to address market failures such as asymmetric information, lack of competition in the markets, or insufficient infrastructure. These failures make it difficult for certain population groups to use formal financial services.

We use micro-data from surveys to study the determinants of using formal financial services as a proxy of financial inclusion. Particularly, we rely on the Peruvian Household Survey (ENAHO 2011) to identify factors conditioning the likelihood of using financial services by households and enterprises. We incorporate four levels of information (individuals, households, towns and regions) in our regressions. Identifying the characteristics affecting the decision to participate in the formal financial system may help in designing policies that promote financial inclusion.

Although financial inclusion has become a key issue, there are still only a few theoretical and empirical studies that focus on the determinants of financial inclusion from a microeconomic point of view. From a macroeconomic point of view, the seminal article by Goldsmith (1969), demonstrating the relationship between financial and economic development, has generated much interest (De Gregorio and Guidotti, 1995; Demetriades and Hussein, 1996; Arestis and Demetriades, 1997; Khan, 2001; Calderon and Lui, 2003; and Christopoulos and Tsonias, 2004, among others). However, despite the large number of theoretical and empirical studies documenting a strong positive relationship between economic growth and financial development, some authors claim that in order to gain a better understanding of the topic, we need to look beyond this relationship. ${ }^{5}$ The question is still a topic for discussion, in part because of the large number of non-financial factors (e.g. technological improvements, regulation, etc.) that determine the quality of financial services.

From a microeconomic point of view, studies aim to analyse the determinants of financial inclusion and quantify the impact of the different factors affecting participation in the formal financial system. For households, the use of financial products (savings, credit, insurance, etc.) improves the possibilities of consumption, and can smooth the income cycles generated by unexpected shocks or discontinuous income flows, thus optimising inter-temporal consumption and improving well-being. A micro-data based paper by Allen et al. (2012) estimates several Probit models for a total of 123 countries to analyse the relationship between financial inclusion and individual- and country-level variables, such as regulatory aspects, the implementation

${ }^{5}$ See Levine (1997) for a complete discussion of the relationship between financial development and economic growth. 
of policies and alternative banking designs. These authors found that greater financial inclusion has a positive correlation with better access to formal financial services (lower banking costs, greater proximity to bank branch offices and reduced documentation requirements). Living in rural areas and low income are negatively correlated with financial inclusion. ${ }^{6}$

The use of financial products also helps enterprises to take investment decisions that would be difficult to achieve using only the funds generated by the economic activity itself. Investment or spending needs are not necessarily synchronised with the inflow and outflow of funds generated by the productive process and they may occur at a time when there are insufficient savings available to meet such needs. Dupas and Robinson (2009) show that financial inclusion has a positive impact on productive investment, while a positive and significant relationship has been demonstrated between the use of credit and the growth of enterprises, particularly for smaller companies (Carpenter and Petersen, 2002).

This study aims to contribute to the literature on the determinants of financial inclusion for the case of Peru which is considered to have one of the best environments for financial inclusion in the world. ${ }^{7}$ To the best of our knowledge, there are no studies from the demand point of view that analyse the financial inclusion problem. Our paper tries to fill this gap by shedding some light on the link between financial inclusion and individual characteristics.

The rest of the paper is organised as follows: Section 2 presents our measurement strategy and the data, Section 3 describes the methodology and the findings, and Section 4 discusses the main conclusions and some economic policy recommendations derived from the analysis.

\section{Measurement strategy and data}

Measuring financial inclusion is not straightforward and it is particularly challenging for less developed economies due to the scarcity of information.

Traditionally, financial inclusion has been approached using supply-side indicators such as banking penetration (users of financial services over the GDP) or financial depth (private credit over GDP). ${ }^{8}$ However, these kinds of indicators do not take into account

\footnotetext{
${ }^{6}$ The authors find similar results with respect to savings.

${ }^{7}$ Global Microscope on the Microfinance Business Environment (2013).

${ }^{8}$ Banking penetration in Peru is almost three times higher than twenty years ago and the level of financial depth is more than five times higher for the same period.
} 
how these figures are distributed among the population and therefore are not an accurate way of measuring the degree of inclusiveness of a financial system.

Financial inclusion refers to a set of ideas that include the use of banking services by unbanked people, the democratisation of credit, the quality of financial services, sustainability, greater range of financial services on offer, and access to finance, among others. However, financial inclusion as a whole does not mean use of financial services by all, at any cost. Financial inclusion defines a process that aims to ensure that everyone who wants to use financial services has access to them at affordable prices, provided for customers in a convenient and responsible fashion. Also, supply conditions of these products need to be profitable for financial institutions. We approach the study of financial inclusion in terms of use of and access to formal financial services. This definition provides a first approximation to the link between financial systems and individuals. ${ }^{9}$

We construct our variable of interest by computing the likelihood of an individual using formal financial services. ${ }^{10}$ A household or enterprise is included in the banking system if it falls into at least one of the following categories: it receives interest on one or more financial products, it has a mortgage loan, or it carries out online banking transactions. ${ }^{11}$ Thus, financial inclusion is a binary variable that takes the value 1 if the person fulfils at least one of the three conditions, and 0 otherwise. We consider households, in contrast to enterprises, as the individuals who are employees or independent workers, workers without wage (e.g. housewife), or employers with less than five employees. We decided to include this group of employers as representative of households due to the important interaction between personal and business finance for small enterprises. In a recent paper, Attanasio et al. (2011) show that more than half of the microcredits granted to small businesses were used for household purposes and not for the business. The most common uses are the purchase of electrical appliances for the house, paying for household loans, and smoothing the seasonality of consumption. These uses make sense from an economic theory point of view, but do not coincide with the objectives of the party that granted the loan. ${ }^{12}$ In terms of finance, the behaviour of these agents is more similar to households than to enterprises. We define enterprises as employers with five or more but fewer than 100 employees.

\footnotetext{
${ }_{9}^{9}$ From a microeconomic perspective, the few attempts to measure financial inclusion focus on different indicators to proxy access and use of banking services (Allen et al., 20 I2; Demirgüç-Kunt and Klapper, 20I 2;AFI, 20I3).

${ }^{10} \mathrm{~A}$ lack of relevant information has meant we have been unable to take into account the issues related to the quality of formal financial services.

${ }^{11}$ The definition for the endogenous variable is the best estimate that can be obtained using ENAHO information, which is not specifically financial. This is not a significant problem, given that our objective is not to predict the levels of financial inclusion, but to analyse the effects of the socioeconomic characteristics of individuals on financial inclusion (and exclusion).

${ }^{12}$ Banks face the uncertainty of whether households with a self-employed activity that ask for a loan can generate sufficient funds to repay it, regardless of whether this money is being used for purposes related to such self-employment.
} 
We use information from the 2011 National Household Survey (ENAHO), developed by the Instituto Nacional de Estadística y Tecnologías de la Información (INEI). Although the ENAHO does not specifically address financial inclusion, we take advantage of its data quality and the coverage. The ENAHO is representative of the whole country and covers both urban and rural areas in the 24 administrative departments and the Constitutional Province of Callao. ${ }^{13}$ These departments are divided into eight geographical regions: Metropolitan Lima, Costa Norte, Costa Centro, Costa Sur, Sierra Norte, Sierra Centro, Sierra Sur and Selva. The population for our study is defined as all households in urban and rural areas of the country. The survey is published both quarterly and annually ${ }^{14}$, and we use the latest annual survey available from 2011 which is based on a probabilistic multi-stage sample, stratified by geographical areas. The size of the sample is 26,456 households, 16,368 in urban areas and 10,088 in rural areas. ${ }^{15}$

Table 1 shows the distribution of the percentage of individuals holding financial products by income level, and show that individuals with higher income are the most banked. These figures are very similar to those obtained from the Global Findex, although they are slightly underestimated in all cases except for the richest individuals. ${ }^{16}$ We observe few banked individuals in the lowest income quintile, and even in the highest income quintile, the percentage of people with a bank account is only slightly above $50 \%$. For this highest income level, this participation rate in developed countries is nearly $100 \%$, and so this suggests that there are characteristics other than incomerelated issues affecting the level of financial inclusion.

Table 1. Usage of formal financial services

\begin{tabular}{lcc}
\hline Income Quintile & Households & Enterprises \\
\hline Quintile 1 (poorest) & $2 \%$ & $1 \%$ \\
\hline Quintile 2 & $8 \%$ & $5 \%$ \\
\hline Quintile 3 & $14 \%$ & $9 \%$ \\
\hline Quintile 4 & $24 \%$ & $15 \%$ \\
\hline Quintile 5 (richest) & $52 \%$ & $70 \%$ \\
\hline
\end{tabular}

SOURCE: OWN ELABORATION WITH DATA FROM ENAHO 2011

\footnotetext{
${ }^{13}$ Members of the armed forces living in barracks, camps, on board ships, etc. are excluded from the sample since they are not part of the population under study. Also excluded are people who live in collective housing (hotels, hospitals, institutions, religious retreats, prisons, etc.).

${ }^{14}$ Households are visited monthly, giving rise to quarterly and annual surveys with different levels of representativeness.

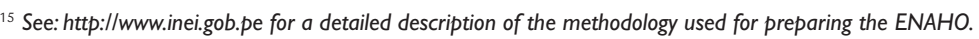

${ }^{16}$ According to Global Findex information, the percentages using banking services by income levels in quintiles I to 5 are $6 \%, 10 \%$, $16 \%, 33 \%$ and $47 \%$, respectively.
} 


\section{Methodology and empirical results}

This section estimates several Probit models to analyse the links between financial inclusion and some variables of interest. We aim to identify the characteristics of households and enterprises that use banking services, taking into account socioeconomic determinants and geographical factors.

We compute the probability of an individual belonging to the group under study, those included in the formal financial system, to gain some insights regarding the profile of households and enterprises holding financial products. Given that the endogenous variable is a binary response - i.e. whether households, $y_{i h}$, and enterprises, $y_{i e}$, use formal financial services - the dependent variables can only take the values 0 or 1 .

Let us assume that the decision to use formal financial services depends on a latent variable $y^{*}$ which is determined by a set of exogenous variables, included in vector $x^{\prime}$, so that:

$$
\begin{gathered}
y_{i j}^{*}=x_{i j}^{\prime} \beta_{j}+u_{i j} \\
y_{i j}=1 \text { if } y_{i j}^{*}>0 ; y_{i j}=0 \text { if } y_{i j}^{*} \leq 0
\end{gathered}
$$

where the subscript $i$ represents individuals and $j \in\{h, e\}$, with $h$ representing households and $e$ enterprises. $\beta$ is a vector of parameters and $u$ is a normally distributed error term with mean 0 and variance 1 .

There is a critical threshold, $y_{i}$ so that if $y_{i}^{*}$ exceeds $y_{i}$ then a household or enterprise has a bank account. $y_{i}$ is not observable either, and we assume that it is distributed normally with the same mean and variance. Thus it is possible to estimate the parameters of interest, $\beta$, to obtain information on $y_{i}^{*}$.

$$
P_{i}=P\left(y_{i}=1 \mid x^{\prime}\right)=P\left(y_{i} \leq y_{i}^{*}\right)=P\left(Z_{i} \leq \beta x_{i}^{\prime}\right)=F\left(\beta x_{i}^{\prime}\right)
$$

where $Z$ is a standard normal variable, $Z \sim N\left(0, \sigma^{2}\right)$ and $F=\left(\frac{1}{\sqrt{2 \pi}}\right) \int_{-\infty}^{\beta x_{i}^{2}} e^{-Z^{2} / 2} d z$ is the cumulative distribution function of a normal variable.

We estimate model (1) by Maximum Likelihood as a series of Probit models. In total, we present three regressions for households and three for enterprises that incorporate different information levels. The first regression includes individuals, households and neighbourhoods; the second adds towns; and the third regression adds regions. This is a useful strategy for the robustness checks of our estimates. 
The marginal effects on the latent variable are calculated from the different coefficients estimated in the models. Given that $E\left(y^{*} \mid x^{\prime}\right)=x^{\prime} \beta$, the interpretation of these marginal effects is similar to that obtained in linear regression models, where the coefficients represent the change in the probability of using banking services when $x_{j} \in\left\{x^{\prime}\right\}$ change, all other things being equal.

\subsection{Drivers of financial inclusion for households}

We use significant correlations to determine those factors that could affect the probability of financial inclusion for households. ${ }^{17}$ Detailed descriptions of the explanatory variables in $x^{\prime}$ are included in Table A1 in the Appendix. Our settings include variables related to the individual and their environment by starting at the narrowest level, individuals, and moving outwards as far as regions. Table 2 shows the estimates.

The first regression (column 1 of Table 2), includes variables at individual and household level and a variable that refers to neighbourhoods. ${ }^{18}$ As observed, most of the individual level variables are significant at conventional levels and all of them have the expected sign. Living in rural areas, being a woman, having a low educational level and low income, and being single appear as significant factors that reduce the likelihood of using financial products. These results are in line with those of Allen et al. (2012). The factors with the biggest impact on the probability of using banking services include living in a rural environment (reduces the likelihood by $3 \%$ compared to an otherwise identical individual living in an urban area), literacy (increases the likelihood by $3 \%$ compared to an illiterate individual) and income (increases the likelihood by around 3.5\% for each income quintile, taking as a control group the highest income level quintile). Being self-employed or an employer does not make any difference in terms of financial inclusion compared to our reference group, being an employee. However, unpaid family members (workers for the family business who do not perceive a wage ${ }^{19}$ ) are less likely to be financially included even when controlling by individual and household income. This suggests that what matters regarding inclusion is having a paid job rather than different working status (e.g. employer or employee). Finally, age has no direct effect on financial inclusion.

\footnotetext{
${ }^{17}$ Notice that in the definition of individuals we include those employers with fewer than four employees, since we consider that they represent the behaviour of households rather than enterprises.

${ }^{18}$ We also run separate regressions that incorporate this information by level. The first only includes individual characteristics, the second also incorporates the variables for households and, the third includes the three levels: individual, household and neighborhood. We only present the third regression for space restrictions. The results are available upon request.

${ }^{19}$ OECD definition for unpaid family members (working in an establishment) includes all persons living in the household(s) of the proprietor(s) of the owning enterprise and working in or for the establishment without regular pay for at least one third of the normal working hours of the establishment. Individual countries may find it necessary to either restrict or extend this definition to take account of their own culture and economy.
} 
Variables referring to the household and the neighbourhood are organised, at the same time, into three groups: income and assets, expenditure, and a third group of qualitative information reflecting household status in terms of deficit and surplus.

In the first group, there are two significant and positive variables referring to income, net and non-wage. Receiving any kind of remittance or transfer, either from abroad or domestic and public (Juntos, public transfer programme for poor people), has no direct impact on promoting financial inclusion. This may be because these transfers are often received through specialised money transfer businesses that do not require a bank account to receive money. We also find a negative relationship between the number of people receiving income in the household and the use of financial products, although its impact on financial inclusion is low. This could reflect a substitution effect due to the costs of using financial services, which makes people in the same household share financial products. Thus, if there is already one person in the household (normally the head of household) who has a financial product, the other household members may share this product rather than acquiring a new one for their personal use.

To account for the effect of household assets, we include the variable home ownership which increases the probability of using banking services by $2 \%$, possibly because ownership of an asset such as a house may provide the sort of guarantee that banks often seek as collateral for loans. Property owners are more likely to fulfil the documentary requirements and guarantees than those who are not home owners.

The second group refers to expenditure and consists of information for households and neighbourhoods. For households, general and specific (e.g. mobile phone) expenditure are highly significant and have a positive effect on financial inclusion. We also include administrative data on neighbourhood expenditure as a proxy for the availability of the access points to the formal financial system. High expenditure neighbourhoods may be attractors for banks to open branches or ATMs to capture a potential demand. However, per capita household expenditure for the neighbourhood is non-significant after controlling for the expenditure variables at household level.

Finally, the last group includes some additional variables of interest, such as whether a household runs a surplus or deficit. The results show that those households in financial need are more likely to use banks than those having the capacity to save, and this represents one of the factors with the greatest impact on financial inclusion. Our estimates show that the capacity to save is not a significant factor for financial inclusion ${ }^{20}$, a find-

${ }^{20}$ This result is in line with those obtained by Collins et al., 2009. 
ing potentially related to alternative options outside the formal financial system. While solving the surplus issue is straightforward, simply by putting the money "under the mattress", looking for a loan may be a more difficult solution. Thus, people are more likely to go to banks when in need of money rather than to put their money in saving accounts. Regarding the importance of financial services for poor households, it is not obvious which is the most valuable in terms of welfare. Microcredits have focused on loans as an important product for poor people, although those in favour of the savings programmes consider saving to be the fundamental need for these types of households.

In our second regression, column 2 of Table 2, we include a larger information level in order to capture issues related to the access dimension through the market size effect. We assume that population density may have an effect on access to formal financial services through the availability of access points such as ATMs, bank branches or banking correspondents. Once we control for individual and household aspects, town size appears to be a good proxy to analyse the effect of access as a driver for financial inclusion. Our estimates show that a scale effect appears in less populated areas. Living in towns with fewer than 401 households, where access to the financial system may be limited, reduces the likelihood of using banking services, as banks, seeking scale economies, have more incentives to locate branches in densely-populated areas.

Finally, we include the Peruvian regions in our regressions as a robustness check. We try to capture idiosyncratic features, sometimes unobservable, such as public programmes or cultural issues that may differ from region to region, and affect financial inclusion. These region dummies have a significant effect on financial inclusion although, as for the population size variables, the magnitude of the impact is still relatively small. People living in Costa Centro and Sierra Norte are less likely to use formal financial services than those living in Lima Metropolitana. However, people living in Sierra Sur and Selva are more likely to be financially included. Looking at the supply-side, the larger number of access points to the formal financial system (e.g. bank branches, ATMs and banking correspondents) could be an explanation for Sierra Sur. By contrast, access to the formal financial system does not seem to be the case for Selva; adding up all the access points, there are fewer in the Selva region than in Lima Metropolitana. The positive and significant sign that we find for Selva might be the result of public financial inclusion programmes developed for remote and disadvantaged areas that have been carried out in this region. These programmes compensate the lack of incentives for private companies to set up in these areas, a lack that generates a great risk of social exclusion.

Our estimates are robust to different specifications. 
Table 2. Financial Inclusion in Peruvian households

\begin{tabular}{|c|c|c|c|}
\hline Banked households $(1 / 0)$ & (1) & $(2)$ & (3) \\
\hline Rural & $\begin{array}{c}-0.0335627^{* * *} \\
(0.00367)\end{array}$ & $\begin{array}{c}-0.0363028^{* * *} \\
(0.00479)\end{array}$ & $\begin{array}{c}-0.0323746^{\star \star *} \\
(0,00363)\end{array}$ \\
\hline Woman & $\begin{array}{c}-0.0089877^{* * *} \\
(0.00323)\end{array}$ & $\begin{array}{c}-0.0088927^{\star * *} \\
(0.00323)\end{array}$ & $\begin{array}{c}-0.0088392^{\star * *} \\
(0.0032)\end{array}$ \\
\hline Single & $\begin{array}{c}-0.0088973^{\star *} \\
(0.00381)\end{array}$ & $\begin{array}{c}-0.0091609^{* *} \\
(0.00381)\end{array}$ & $\begin{array}{c}-0.0082149^{\star \star *} \\
(0.0038)\end{array}$ \\
\hline Literate & $\begin{array}{c}0.023656^{* * *} \\
(0.00893)\end{array}$ & $\begin{array}{c}0.0238766^{* * *} \\
(0.00893)\end{array}$ & $\begin{array}{c}0.0234017^{\star * \star} \\
(0.00888)\end{array}$ \\
\hline Worker without wage & $\begin{array}{c}-0.0206411^{* * *} \\
(0.00435)\end{array}$ & $\begin{array}{c}-0.0202361^{\star \star *} \\
(0.00435)\end{array}$ & $\begin{array}{c}-0.0210774^{* * *} \\
(0.00429)\end{array}$ \\
\hline Self-employed worker & $\begin{array}{c}-0,0035034 \\
(0.00372)\end{array}$ & $\begin{array}{l}-0,00349 \\
(0.00372)\end{array}$ & $\begin{array}{c}-0.0040472 \\
(0.00368)\end{array}$ \\
\hline Employer (<5 people) & $\begin{array}{c}-0,0053327 \\
(0.00788)\end{array}$ & $\begin{array}{c}-0,0054119 \\
(0.00784)\end{array}$ & $\begin{array}{c}-0.0055497 \\
(0.0078)\end{array}$ \\
\hline Age & $\begin{array}{c}0,0000813 \\
(0.00065)\end{array}$ & $\begin{array}{l}0,000035 \\
(0.00065)\end{array}$ & $\begin{array}{c}0.0001441 \\
(0.00065)\end{array}$ \\
\hline Age-squared & $\begin{array}{c}-0,0000094 \\
(0.00001)\end{array}$ & $\begin{array}{c}-0,00000887 \\
(0.00001)\end{array}$ & $\begin{array}{c}-0.00000979 \\
(0.00001)\end{array}$ \\
\hline Education & $\begin{array}{c}0.0084771^{\star \star \star} \\
(0.00089)\end{array}$ & $\begin{array}{c}0.008488^{\star \star \star} \\
(0.00089)\end{array}$ & $\begin{array}{c}0.0083258^{* * *} \\
(0.00089)\end{array}$ \\
\hline Income quintile 1 & $\begin{array}{c}-0.048868^{\star \star \star} \\
(0.00436)\end{array}$ & $\begin{array}{c}-0.0477838^{* * *} \\
(0.00447)\end{array}$ & $\begin{array}{c}-0.0484576^{\star * *} \\
(0.00429)\end{array}$ \\
\hline Income quintile 2 & $\begin{array}{c}-0.0414314^{* * *} \\
(0.00415)\end{array}$ & $\begin{array}{c}-0.0406367^{* * *} \\
(0.00418)\end{array}$ & $\begin{array}{c}-0.0415855^{\star * *} \\
(0.00407)\end{array}$ \\
\hline Income quintile 3 & $\begin{array}{c}-0.0315131^{\star * *} \\
(0.00413)\end{array}$ & $\begin{array}{c}-0.0308936^{\star * *} \\
(0.00413)\end{array}$ & $\begin{array}{c}-0.0315438^{* * *} \\
(0.00406)\end{array}$ \\
\hline Income quintile 4 & $\begin{array}{c}-0.0157301^{\star * *} \\
(0.00407)\end{array}$ & $\begin{array}{c}-0.0154926^{\star * *} \\
(0.00407)\end{array}$ & $\begin{array}{c}-0.0156952^{\star * *} \\
(0.00403)\end{array}$ \\
\hline Household expenditure & $\begin{array}{c}0.000000531^{* * *} \\
(0.000)\end{array}$ & $\begin{array}{c}0.000000524^{* * *} \\
(0.000)\end{array}$ & $\begin{array}{c}0.00000053^{* * *} \\
(0.000)\end{array}$ \\
\hline Net annual household income & $\begin{array}{c}0.00000014^{*} \\
(0.000)\end{array}$ & $\begin{array}{c}0.000000144^{* *} \\
(0.000)\end{array}$ & $\begin{array}{c}0.000000145^{* *} \\
(0.000)\end{array}$ \\
\hline Non-wage annual income & $\begin{array}{c}0.000000515^{\star *} \\
(0.000)\end{array}$ & $\begin{array}{c}0.000000518^{* *} \\
(0.000)\end{array}$ & $\begin{array}{c}0.000000488^{* *} \\
(0.000)\end{array}$ \\
\hline Annual income remittances from abroad & $\begin{array}{c}-0,000000317 \\
(0.000)\end{array}$ & $\begin{array}{c}-0,000000343 \\
(0.000)\end{array}$ & $\begin{array}{c}-0.000000224 \\
(0.000)\end{array}$ \\
\hline Annual income private transfers & $\begin{array}{c}-0,000000209 \\
(0.000)\end{array}$ & $\begin{array}{c}-0,0000002 \\
(0.000)\end{array}$ & $\begin{array}{c}-0.000000158 \\
(0.000)\end{array}$ \\
\hline Annual income public transfers & $\begin{array}{c}-0,000000115 \\
(0.000)\end{array}$ & $\begin{array}{c}-0,000000108 \\
(0.000)\end{array}$ & $\begin{array}{c}-0.000000106 \\
(0.000)\end{array}$ \\
\hline $\begin{array}{l}\text { Annual household mobile } \\
\text { phone expenditure }\end{array}$ & $\begin{array}{c}0.0000102^{\star * \star} \\
(0.000)\end{array}$ & $\begin{array}{c}0.0000104^{\star \star \star} \\
(0.000)\end{array}$ & $\begin{array}{c}0.00000941^{* * *} \\
(0.000)\end{array}$ \\
\hline Household income receivers & $\begin{array}{c}-0.0084818^{* * *} \\
(0.00135)\end{array}$ & $\begin{array}{c}-0.0084998^{* * *} \\
(0.00135)\end{array}$ & $\begin{array}{c}-0.0083389^{\star * *} \\
(0.00134)\end{array}$ \\
\hline Poor household & $\begin{array}{l}-0,00177 \\
(0.00546)\end{array}$ & $\begin{array}{c}-0,0019589 \\
(0.00545)\end{array}$ & $\begin{array}{c}-0.0007866 \\
(0.00548)\end{array}$ \\
\hline Home ownership & $\begin{array}{c}0.0194931^{\star * *} \\
(0.0033)\end{array}$ & $\begin{array}{c}0.0199194^{\star \star *} \\
(0.0033)\end{array}$ & $\begin{array}{c}0.0184138^{\star * *} \\
(0.00332)\end{array}$ \\
\hline Surplus-household & $\begin{array}{c}0,0041189 \\
(0.00527)\end{array}$ & $\begin{array}{c}0,0044836 \\
(0.00528)\end{array}$ & $\begin{array}{c}0.0029978 \\
(0.00515)\end{array}$ \\
\hline
\end{tabular}




\begin{tabular}{|c|c|c|c|}
\hline Overdrawn-household & $\begin{array}{c}0.0329358^{\star \star \star} \\
(0.00464)\end{array}$ & $\begin{array}{c}0.0327126^{\star \star *} \\
(0.00465)\end{array}$ & $\begin{array}{c}0.0329658^{\star \star \star} \\
(0.00468)\end{array}$ \\
\hline Expenditure per capita (neighbourhoods) & $\begin{array}{c}-4,83 E-08 \\
(0.000)\end{array}$ & $\begin{array}{c}-0,0000002 \\
(0.000)\end{array}$ & $\begin{array}{c}0.0000000737 \\
(0.000)\end{array}$ \\
\hline Areas of 20,001 to 100,000 households & & $\begin{array}{c}-0,0027653 \\
(0.00421)\end{array}$ & \\
\hline Areas of 10,001 to 20,000 households & & $\begin{array}{c}-0,0005576 \\
(0.00568)\end{array}$ & \\
\hline Areas of 4,001 to 10,000 households & & $\begin{array}{c}0,0050611 \\
(0.00609)\end{array}$ & \\
\hline Areas of 401 to 4,000 households & & $\begin{array}{c}-0,0064287 \\
(0.00584)\end{array}$ & \\
\hline Areas of 401 households & & $\begin{array}{c}-0.0264015^{\star \star \star} \\
(0.00603)\end{array}$ & \\
\hline Costa Norte & & & $\begin{array}{c}0.0059485 \\
(0.00548)\end{array}$ \\
\hline Costa Centro & & & $\begin{array}{c}-0.0138846^{\star * *} \\
(0.00482)\end{array}$ \\
\hline Costa Sur & & & $\begin{array}{l}0.0056955 \\
(0.00654)\end{array}$ \\
\hline Sierra Norte & & & $\begin{array}{c}-0.0203037^{* * *} \\
(0.00739)\end{array}$ \\
\hline Sierra Centro & & & $\begin{array}{c}-0.0000784 \\
(0.00589)\end{array}$ \\
\hline Sierra Sur & & & $\begin{array}{c}0.016544^{\star *} \\
(0.00666)\end{array}$ \\
\hline Selva & & & $\begin{array}{c}0.0135484^{* *} \\
(0.00609)\end{array}$ \\
\hline
\end{tabular}

***, ** and * denotes significance to $99 \%, 95 \%$ and $90 \%$ respectively. Values in brakets are the standard errors. SOURCE: OWN ELABORATION WITH DATA FROM ENAHO $201 \mathrm{I}$

\subsection{Drivers of financial inclusion for enterprises}

In this section, we analyse financial inclusion from the point of view of enterprises, namely those which carry out a business activity. Enterprises are defined as employers with a minimum of 5 and fewer than 100 employees. We focus on micro- and smallenterprises to study whether their behaviour is different from that of households.

We follow the same structure as in the regressions for households by starting with individual- and company-specific variables, then towns, and finally regions. The results of the estimates are presented in Table 3, where it can be observed that being literate has a greater effect on financial inclusion among enterprises than households (3.7\% compared with $2.3 \%$ ). However, the importance of education, once we control for literacy, has a very similar effect for both households and enterprises, albeit slightly greater for the latter. Formality, understood as the legal registration of the company and the standardised presentation of business accounts, appears as another relevant factor for financial inclusion. Formal enterprises are more likely to 
use banking services than informal enterprises ( $3 \%$ greater probability). This could be because it is easier for formal enterprises to use financial services, given the greater transparency of their business which enables banks to assess risk and consequently makes such customers more interesting to financial institutions. However, the restrictions for financial inclusion are determined not only by the supply side; issues related to formality from the demand side are also important for understanding the factors affecting financial inclusion. The informality of enterprises leads to a self-exclusion phenomenon that reflects the fear of employers who are part of the shadow economy of being controlled by the authorities. This fear means that their demand for financial services may be satisfied by informal channels that escape legal control, generating a self-selection from the demand side.

The income effect is also significant for quintiles 1 and 2, which are less likely to use financial services than quintile 5 ( $4 \%$ and $3 \%$ respectively). We find no difference between income quintiles 3 and 4 compared to 5 . The dummy variable to account for company profits is significant but has a negligible impact, perhaps because the income effect is already captured with the variables for the entrepreneur's income.

In terms of geographical issues, town size, which captures scale effects, is not significant for enterprises. A potential explanation could be that the benefits of using formal financial services might outweigh distance-related costs for enterprises, who are able to afford it. This does not hold for households, however, because they are smaller units and costs may exceed benefits.

Finally, we also control for region-specific characteristics and we find that Sierra Centro is the only region more disadvantaged than Lima Metropolitana. These results are robust to different specifications. They remain similar in terms of magnitude and the variable for marital status is the only one to become non-significant when controlling for regions.

Table 3. Financial Inclusion in the Peruvian enterprises

\begin{tabular}{lccc}
\hline Banked enterprise & $(1)$ & $(2)$ & $(3)$ \\
\hline Woman & 0.0118 & 0.0121 & 0.011521 \\
& $(0.0087)$ & $(0.0089)$ & $(0.0083)$ \\
\hline Single & $-0.0133^{*}$ & $-0.0131^{\star}$ & -0.0116099 \\
& $(0.0072)$ & $(0.0073)$ & $(0.00712)$ \\
\hline Literate & $0.0369^{\star *}$ & $0.0371^{\star *}$ & $0.0363125^{\star *}$ \\
& $(0.0154)$ & $(0.0153)$ & $(0.01502)$ \\
\hline Age & 0.0001 & 0.00007 & 0.0001468 \\
& $(0.0015)$ & $(0.0015)$ & $(0.0014)$ \\
\hline Age-squared & -0.0000096 & -0.000009 & -0.00000918 \\
& $(0.00002)$ & $(0.00002)$ & $(0.00001)$ \\
\hline Education & $0.00998^{\star * *}$ & $0.0100^{\star * *}$ & $0.0095449^{* * *}$ \\
& $(0.0020)$ & $(0.0020)$ & $(0.00186)$ \\
\hline
\end{tabular}




\begin{tabular}{|c|c|c|c|}
\hline Poor household & $\begin{array}{l}-0.0149 * \\
(0.0082)\end{array}$ & $\begin{array}{l}-0.0151^{\star} \\
(0.0082)\end{array}$ & $\begin{array}{c}-0.0133353^{*} \\
(0.00774)\end{array}$ \\
\hline Income quintile 1 & $\begin{array}{c}-0.0374^{\star \star \star} \\
(0.0073)\end{array}$ & $\begin{array}{c}-0.0378^{* \star *} \\
(0.0074)\end{array}$ & $\begin{array}{c}-0.0339839^{\star * *} \\
(0.00705)\end{array}$ \\
\hline Income quintile 2 & $\begin{array}{c}-0.0250^{\star \star \star} \\
(0.0068)\end{array}$ & $\begin{array}{c}-0.0256^{\star \star \star} \\
(0.0068)\end{array}$ & $\begin{array}{c}-0.0228869^{* * *} \\
(0.00654)\end{array}$ \\
\hline Income quintile 3 & $\begin{array}{c}-0.0075 \\
(0.008)\end{array}$ & $\begin{array}{c}-0.0079 \\
(0.008)\end{array}$ & $\begin{array}{c}-0.0060563 \\
(0.0077)\end{array}$ \\
\hline Income quintile 4 & $\begin{array}{c}-0.00996 \\
(0.0074)\end{array}$ & $\begin{array}{l}-0.0102 \\
(0.0072)\end{array}$ & $\begin{array}{c}-0.009325 \\
(0.00685)\end{array}$ \\
\hline Formal enterprise & $\begin{array}{l}0.0286^{\star} \\
(0.0178)\end{array}$ & $\begin{array}{c}0.029^{*} \\
(0.0178)\end{array}$ & $\begin{array}{c}0.0253534 \\
(0.01684)\end{array}$ \\
\hline Profit & $\begin{array}{c}0.00000008^{*} \\
(0.0000)\end{array}$ & $\begin{array}{c}0.00000008^{*} \\
(0.0000)\end{array}$ & $\begin{array}{c}0.0000000758^{\star} \\
(0.0000)\end{array}$ \\
\hline Areas of 20,001 a 100,000 households & & $\begin{array}{l}-0.0056 \\
(0.0074)\end{array}$ & - \\
\hline Areas of 10,001 a 20,000 households & & $\begin{array}{l}-0.0049 \\
(0.0128)\end{array}$ & - \\
\hline Areas of 4,001 a 10,000 households & & $\begin{array}{c}-0.0002 \\
(0.01)\end{array}$ & - \\
\hline Areas of 401 a 4,000 households & & $\begin{array}{c}0.0052 \\
(0.0107)\end{array}$ & $\begin{array}{l}- \\
-\end{array}$ \\
\hline Costa Norte & & $\begin{array}{l}- \\
-\end{array}$ & $\begin{array}{c}-0.0080677 \\
(0.00939)\end{array}$ \\
\hline Costa Centro & & - & $\begin{array}{c}0.0006698 \\
(0.01386)\end{array}$ \\
\hline Costa Sur & & - & $\begin{array}{c}-0.0099135 \\
(0.00943)\end{array}$ \\
\hline Sierra Norte & & - & $\begin{array}{c}-0.0086962 \\
(0.01151)\end{array}$ \\
\hline Sierra Centro & & - & $\begin{array}{c}-0.0168817^{* *} \\
(0.00795)\end{array}$ \\
\hline Sierra Sur & & - & $\begin{array}{l}0.000127 \\
(0.01056)\end{array}$ \\
\hline Selva & & $\begin{array}{l}- \\
-\end{array}$ & $\begin{array}{c}0.0041584 \\
(0.01044)\end{array}$ \\
\hline
\end{tabular}

***, ** and * denotes significance to $99 \%, 95 \%$ and $90 \%$ respectively. Values in brakets are the standard errors. SOURCE: OWN ELABORATION WITH DATA FROM ENAHO 2011

\section{Main conclusions and policy implications}

Financial inclusion is important for sustainable economic growth and the improvement of social well-being. The question of how to build inclusive financial systems is challenging, and this is particularly important in developing countries and emerging markets, where banking penetration rates are relatively low. This paper illustrates the socioeconomic characteristics affecting the use of the financial system by both households and enterprises. We build our proxy to study financial inclusion with information from the Household Survey conducted in Peru (ENAHO). Our econometric 
strategy is based on the study of factors that could affect the decision to be included in the formal financial system, by starting from the narrowest level of aggregation in the data (individuals) up until the broadest (regions). We find that individual characteristics such as being a woman, living in a rural area, or having a low income and educational level reduce the likelihood of being included in the formal financial system. Also, households with cash flow problems are more likely to use banking services than those with savings. The results are similar for enterprises, with the only difference being that education seems to be more important for enterprises than for households in terms of fostering financial inclusion. In the case of enterprises, it is also interesting to observe the role of formality. Formal enterprises are more likely to participate in the formal financial system than informal ones, and so fostering formality may be a valuable aid in promoting financial inclusion. Regarding density population variables, we find that scale matters when analysing households but not for enterprises: only households are negatively affected by living in small towns. This is makes sense since the need for formal financial services may be stronger for enterprises.

The regional effects are also more prevalent for households. Whereas for households, we find significant differences with our reference group in four regions, only a single region is disadvantaged when it comes to enterprises.

In terms of the definition of our endogenous variable, we are aware that there could be other relationships with banks that cannot be accounted for in the information from ENAHO. However, although our proxy (users of financial products) is far from perfect, since it may underestimate the number of households that use banking services, it is relatively accurate. We consider that our definition is broad enough to achieve a good proxy for financial inclusion in Peru given that it accounts for more than half of Peruvian households that use banking services, according to World Bank estimates.

Peru has already started to construct a base for financial inclusion, as the Peruvian government has a National Strategy for Social Inclusion, which includes the National Strategy for Financial Inclusion. It is desirable to ensure that financial services can meet the whole demand with appropriate products and access channels. Although financial services are provided more efficiently by the private sector, the goal of implementing inclusive strategies needs a strong commitment from both public and private institutions. Better financial information, including behavioural issues, for households and enterprises, is essential in order to make progress. The role of governments is to mitigate market failures by establishing adequate regulation and policies. People need to be aware of the benefits of having access to financial systems and to understand the consequences of involuntary financial exclusion. Providing financial education is key to achieving this goal. 
Access to the formal financial system is one of the most important ways to prevent exclusion. Peru faces several problems in terms of accessing the formal financial system, due to geography and the dispersion of the population. This access problem has been tackled recently with the development of mobile banking schemes. This promising new model of banking minimizes the problems of access through the use of technology and correspondent banking, which lower banks' operational costs. The combination of technology (mainly the use of mobile phones) and expanded coverage through an extensive network of banking correspondents (stores, drugstores or other establishments providing banking services on behalf of a bank), not only increases access but also increases poor people's trust in formal financial services since they interact with local shopkeepers instead of bankers. Poor customers feel more comfortable when interacting with these agents than with bankers, which in turn makes the interaction easier. There are also other important advantages regarding the significant reduction in waiting times due to the congestion of traditional bank branches and greater security when carrying out transactions compared with ATMs in the street. As a part of the Peruvian National Strategy for Financial Inclusion, in 2012 the government also approved the $e$-Money regulatory framework, which aims to promote financial inclusion by improving access to the financial system without a prohibitively expensive infrastructure investment. This kind of regulation, together with improved technologies and the high mobile phone penetration, would make mobile banking an efficient alternative to traditional, costly branch banking, particularly since it generates a sizeable reduction of product-delivery costs.

\section{References}

Aghion, P. and Bolton, P. (1997). A Theory of Trickle-down Growth and Development with Debt-overhang, Review of Economic Studies, 64, pp. 151-172.

Allen, F., Demirgüç-Kunt, A., Klapper, L. and Martínez Peria, M.S. (2012). The Foundations of financial inclusion. Understanding Ownership and Use of Formal Accounts. Policy Research Working Paper 6290, World Bank, Development Research Group, Finance and Private Sector Development Team, Washington D.C

Aportela, F. (1999). Effects of Financial Access on Savings by Low-Income People, Banco de México Research Department, Chapter 1 of doctoral dissertation, MIT Department of Economics, Cambridge, Mass.

Arestis, P. and Demetriades, P. (1997). Financial development and economic growth: Assessing the evidence, The Economic Journal, 107(442), pp. 783-799.

Ashraf N., Aycinena, C., Martines, A. and Yang, D. (2010a). Remittances and the problem of control: A field experiment among migrants from El Salvador. Mimeo. 
Ashraf, N., Karlan, D. and Yin, W. (2010b). Female empowerment: Further evidence from a commitment savings product in the Philippines, World Development 28(3), pp. 333-344.

Atkinson, A., McKay, S., Kempson, E. and Collard, S. (2006). Levels of Financial Capability in the UK: Results of a baseline survey, Consumer Research, 47, pp. 101-123.

Attanasio, O., Augsburg, B., Haas, R. D., Fitssimons, E. and Harmgart, H. (2011). Group lending or individual lending? Evidence from a randomised field experiment in Mongolia, WP [W11/20], IFS.

Abhijit, B. and Newman, A. (1993). Occupational Choice and the Process of Development, Journal of Political Economy, 101, pp. 274-98.

Banerjee, A., Duflo E., Glennerster R. and Kinnan, C. (2010). The Miracle of Microfinance? Evidence from a Randomised Evaluation, WP [278] MIT Bureau for Research and Economic Analysis of Development, Cambridge, Massachusetts.

Barth, J.R., Caprio Jr, G. and Levine, R. (2008). Bank Regulations Are Changing: For Better or Worse? Mimeo, World Bank, Washington, DC.

Beck, T., Demirgüç-Kunt A. and Levine, R. (2007). Finance, Inequality, and the Poor, Journal of Economic Growth, 12, pp. 27-49.

Beck, T., Demirgüç-Kunt, A. and Martínez Peria, M.S. (2008). Banking Services for Everyone? Barriers to Bank Access and Use Around the World, World Bank Economic Review, 22(3), pp. 397-430.

Beck, T., Demirgüç-Kunt, A. and Martínez Peria, M.S. (2007). Reaching Out: Access to and Use of Banking Services across Countries, Journal of Financial Economics, 85, pp. 234-66.

Calderón, C. and Liu, L. (2003). The direction of causality between financial development and economic growth, Journal of Development Economics, 72(1), pp. 321-334.

Carpenter, R.E. and Petersen, B.C. (2002). Is the growth of small firms constrained by internal finance?, Review of Economics and Statistics, 84(2), pp. 298-309.

Collins, D., Morduch, J., Rutherford, S. and Ruthven, O. (2009). Portfolios of the Poor, Princeton University Press, Princeton.

Christopoulos, D.K., and Tsionas, E.G. (2004). Financial development and economic growth: evidence from panel unit root and cointegration tests, Journal of Development Economics, 73(1), pp. 55-74.

Cull R., Demirgüç-Kunt, A. and Lyman, T. (2012). Financial inclusion and Stability: What Does Research Show?, CGAP Brief 71305, CGAP, Washington, DC.

De Gregorio, J. and Guidotti, P.E. (1995). Financial development and economic growth, World Development, 23(3), pp. 433-448.

Demetriades, P.O. and Hussein, K.A. (1996). Does financial development cause economic growth? Time-series evidence from 16 countries, Journal of Development Economics, 51(2), pp. 387-411.

Demirgüç-Kunt, A. and Klapper, L. (2012). Measuring financial inclusion: The Global Findex Database, WP [6025] World Bank Policy Research, Washington, DC.

Demirgüç-Kunt, A., Detragiache, E. and T. Tressel. (2008). "Banking on the Principles: Compliance with Basel Core Principles and Bank Soundness, Journal of Financial Intermediation, 17(4), pp. 511-42. 
Dupas, P. and Robinson, J. (2009). Savings Constraints and Microenterprise Development: Evidence from a Field Experiment in Kenya, WP [14693], National Bureau of Economic Research, Cambridge, MA.

Financial Action Task Force (FATF) (2011). Anti-money Laundering and Terrorist Financing Measures and Financial Inclusion, FATF/OECD, Paris.

Galor, O. and Seira, J. (1993). Income Distribution and Macroeconomics, Review of Economic Studies, 60 (1), pp. 35-52.

Goldsmith, R.W. (1969). Financial Structure and Development, Yale University Press, New Haven, Vol. 1, p. 969.

Honohan, P. (2008). Cross-Country Variation in Household Access to Financial Services, Journal of Banking and Finance, 32, pp. 2493-500.

Karlan, D. and Sinman, J. (2010). Expanding Credit Access: Using Randomised Supply Decisions to Estimate the Impacts, Review of Financial Studies, 23(1), pp. 433-64.

Karlan, D. and Morduch, J. (2010). Access to Finance, in D. Rodrik and M. Rosensweig (Eds.), Handbook of Development Economics, Vol. 5. , North-Holland, Amsterdam.

Kendall, J., Mylenko, N. and Ponce A. (2010). Measuring Financial Access around the World. WP [5253] World Bank Policy Research, Washington DC.

Khan, A. (2001). Financial development and economic growth, Macroeconomic Dynamics, 5(3), pp. 413-433.

Levine, R. (1997). Financial development and economic growth: views and agenda, Journal of Economic Literature, 35(2), pp. 688-726.

Martin, C., Demirgüç-Kunt, A., Martínez Peria, M.S. and Mohseni-Cheraghlou, A. (2012). Bank Regulation and Supervision around the World: A Crisis Update, World Bank Policy Research Working Paper 6286, Washington DC.

Patrick, H.T. (1966). Financial development and economic growth in underdeveloped countries, Economic Development and Cultural Change, 14(2), pp. 174-189.

Roodman, D. (2012). Due Diligence: An Impertinent Inquiry into Microfinance, Center for Global Development, Washington DC. Available at http://www.cgdev.org/blog/david-roodman-due-diligence-impertinent-inquiry-microfinance. $\square$ 
Appendix A

Variables description

Table A.1.Description of the variables in the household regressions

\begin{tabular}{|c|c|}
\hline Variable & Description \\
\hline Bank user $(0 / 1)$ & $\begin{array}{l}\text { A household is considered to be banked if it falls into one of the } \\
\text { following categories: it has a mortgage, receives interest on some } \\
\text { financial product (savings...) or carries out online banking transactions. }\end{array}$ \\
\hline Rural $(0 / 1)$ & $\begin{array}{l}\text { Dummy that takes the value } 1 \text { if the respondent lives in a rural area } \\
\text { and } 0 \text { otherwise. }\end{array}$ \\
\hline Woman $(0 / 1)$ & $\begin{array}{l}\text { Dummy that takes the value } 1 \text { if the respondent is a woman and } 0 \\
\text { otherwise. }\end{array}$ \\
\hline Single $(0 / 1)$ & $\begin{array}{l}\text { Dummy that takes the value } 1 \text { if the respondent is single and } 0 \\
\text { otherwise. }\end{array}$ \\
\hline Literate & $\begin{array}{l}\text { Dummy that takes the value } 1 \text { if the respondent can read and write } \\
\text { and } 0 \text { otherwise. }\end{array}$ \\
\hline Worker without wage & Person who works for the family business, house-wives, etc... \\
\hline Independent worker $(0 / 1)$ & $\begin{array}{l}\text { Dummy that takes the value } 1 \text { if the respondent is an independent } \\
\text { worker and } 0 \text { otherwise. }\end{array}$ \\
\hline Employee (0/1) & $\begin{array}{l}\text { Dummy that takes the value } 1 \text { if the respondent works for a formal } \\
\text { company and } 0 \text { otherwise. }\end{array}$ \\
\hline Employer $(0 / 1)$ & $\begin{array}{l}\text { Dummy that takes the value } 1 \text { if the respondent is an employer and } 0 \\
\text { otherwise. }\end{array}$ \\
\hline Annual household spending & Total household spending (in soles) \\
\hline Net annual household income & Annual household income (net), (in soles) \\
\hline Non-wage annual income & Monetary income from property rental, (in soles) \\
\hline Annual income remittances from abroad & $\begin{array}{l}\text { Monetary income from remittances received by the household from } \\
\text { abroad, (in soles) }\end{array}$ \\
\hline Annual income private transfers & Monetary income from private transfers, (in soles) \\
\hline Annual income public transfers & Monetary income from public transfers, (in soles) \\
\hline Age & Age in years \\
\hline Educational & Years of education \\
\hline Age squared & Age in years, squared \\
\hline Annual household mobile phone expenditure & Household spending on mobile telephony, (in soles) \\
\hline Recipients of income in household & Number of individuals in the household earning income \\
\hline Poor household & $\begin{array}{l}\text { Dummy that takes the value } 1 \text { if the household is in a condition of } \\
\text { poverty or extreme poverty according to the national measurement } \\
\text { (poverty/extreme poverty line) and } 0 \text { otherwise }\end{array}$ \\
\hline Income quintile $1(0 / 1)$ & $\begin{array}{l}\text { Dummy that takes the value } 1 \text { if the respondent is in the lowest } \\
\text { income quintile and } 0 \text { otherwise. Income quintiles depend on the } \\
\text { income of a country's respondents. }\end{array}$ \\
\hline Income quintile $2(0 / 1)$ & $\begin{array}{l}\text { Dummy that takes the value } 1 \text { if the respondent is in the second } \\
\text { lowest income quintile and } 0 \text { otherwise. Income quintiles depend on } \\
\text { the income of a country's respondents. }\end{array}$ \\
\hline Income quintile $3(0 / 1)$ & $\begin{array}{l}\text { Dummy that takes the value } 1 \text { if the respondent is in the middle } \\
\text { income quintile and } 0 \text { otherwise. Income quintiles depend on the } \\
\text { income of a country's respondents. }\end{array}$ \\
\hline Income quintile $4(0 / 1)$ & $\begin{array}{l}\text { Dummy that takes the value } 1 \text { if the respondent is in the second } \\
\text { highest income quintile and } 0 \text { otherwise. Income quintiles depend on } \\
\text { the income of a country's respondents. }\end{array}$ \\
\hline Per capita income (neighbourhoods) & $\begin{array}{l}\text { Average income of each of the households, in the neighbourhoods of } \\
\text { residence (in soles) }\end{array}$ \\
\hline
\end{tabular}


Table A.1 (Continued)

\begin{tabular}{|c|c|}
\hline Variable & Description \\
\hline Per capita income (neighbourhoods) & $\begin{array}{l}\text { Average income of each of the households, in the neighbourhoods of } \\
\text { residence (in soles) }\end{array}$ \\
\hline Home ownership & $\begin{array}{l}\text { Dummy that takes the value } 1 \text { if the respondent owns a home and } 0 \\
\text { otherwise. }\end{array}$ \\
\hline Household saves & $\begin{array}{l}\text { Dummy that takes the value } 1 \text { if the household has a surplus at the } \\
\text { end of the month and } 0 \text { otherwise. }\end{array}$ \\
\hline Household in debt & $\begin{array}{l}\text { Dummy that takes the value } 1 \text { if the household has a deficit at the end } \\
\text { of the month and } 0 \text { otherwise. }\end{array}$ \\
\hline Towns of 20,001 to 100,000 homes & $\begin{array}{l}\text { Dummy that takes the value } 1 \text { if the respondent lives in a population } \\
\text { centre of } 20,001 \text { to } 100,000 \text { homes and } 0 \text { otherwise. }\end{array}$ \\
\hline Towns of 10,001 to 20,000 homes & $\begin{array}{l}\text { Dummy that takes the value } 1 \text { if the respondent lives in a population } \\
\text { centre of } 10,001 \text { to } 20,000 \text { homes and } 0 \text { otherwise. }\end{array}$ \\
\hline Towns of 4,001 to 10,000 homes & $\begin{array}{l}\text { Dummy that takes the value } 1 \text { if the respondent lives in a population } \\
\text { centre of } 4,001 \text { to } 10,000 \text { homes and } 0 \text { otherwise. }\end{array}$ \\
\hline Towns of 401 to 4,000 homes & $\begin{array}{l}\text { Dummy that takes the value } 1 \text { if the respondent lives in a population } \\
\text { centre of } 401 \text { to } 4,000 \text { homes and } 0 \text { otherwise. }\end{array}$ \\
\hline Towns of fewer than 401 homes & $\begin{array}{l}\text { Dummy that takes the value } 1 \text { if the respondent lives in a population } \\
\text { centre of } 401 \text { homes and } 0 \text { otherwise. }\end{array}$ \\
\hline Costa Norte & $\begin{array}{l}\text { Dummy that takes the value } 1 \text { if the respondent lives in Costa Norte } \\
\text { and } 0 \text { otherwise. }\end{array}$ \\
\hline Costa Centro & $\begin{array}{l}\text { Dummy that takes the value } 1 \text { if the respondent lives in Costa Centro } \\
\text { and } 0 \text { otherwise. }\end{array}$ \\
\hline Costa Sur & $\begin{array}{l}\text { Dummy that takes the value } 1 \text { if the respondent lives in Costa Sur and } \\
0 \text { otherwise. }\end{array}$ \\
\hline Sierra Norte & $\begin{array}{l}\text { Dummy that takes the value } 1 \text { if the respondent lives in Sierra Norte } \\
\text { and } 0 \text { otherwise. }\end{array}$ \\
\hline Sierra Centro & $\begin{array}{l}\text { Dummy that takes the value } 1 \text { if the respondent lives in Sierra Centro } \\
\text { and } 0 \text { otherwise. }\end{array}$ \\
\hline Sierra Sur & $\begin{array}{l}\text { Dummy that takes the value } 1 \text { if the respondent lives in Sierra Sur and } \\
0 \text { otherwise. }\end{array}$ \\
\hline Selva & $\begin{array}{l}\text { Dummy that takes the value } 1 \text { if the respondent lives in Selva and } 0 \\
\text { otherwise. }\end{array}$ \\
\hline
\end{tabular}

SOURCE: OWN ELABORATION

\section{Table A.2. Description of the variables in the enterprise regressions}

\begin{tabular}{ll}
\hline Variable & Description \\
\hline Bank user $(0 / 1)$ & $\begin{array}{l}\text { A company is considered to be banked if it falls into one of the } \\
\text { following categories: it has a mortgage, receives interest on some } \\
\text { financial product (savings...) or carries out online banking transactions. }\end{array}$ \\
\hline Rural $(0 / 1)$ & $\begin{array}{l}\text { Dummy that takes the value } 1 \text { if the respondent lives in a rural area } \\
\text { and } 0 \text { otherwise. }\end{array}$ \\
\hline Woman $(0 / 1)$ & $\begin{array}{l}\text { Dummy that takes the value } 1 \text { if the respondent is a woman and } 0 \\
\text { otherwise. }\end{array}$ \\
\hline Single $(0 / 1)$ & $\begin{array}{l}\text { Dummy that takes the value } 1 \text { if the respondent is single and } 0 \\
\text { otherwise. }\end{array}$ \\
\hline Literate & $\begin{array}{l}\text { Dummy that takes the value } 1 \text { if the respondent can read and write } \\
\text { and } 0 \text { otherwise. }\end{array}$ \\
\hline Age & Age in years \\
\hline Educational level & Years of education \\
\hline age2 & Age in years, squared \\
\hline Poor household & Dummy that takes the value 1 if the household is in a condition of \\
& poverty or extreme poverty according to the national measurement \\
(poverty/extreme poverty line) and 0 otherwise
\end{tabular}


Income quintile $1(0 / 1)$

Income quintile $2(0 / 1)$

Income quintile $3(0 / 1)$

Income quintile $4(0 / 1)$

\begin{tabular}{|c|c|}
\hline Income from independent activity & Net income from the independent activity, (in soles) \\
\hline Net profit of the business & Net profit of the business, (in soles) \\
\hline Annual household spending & Total household spending (in soles) \\
\hline Per capita spending (neighbourhoods) & $\begin{array}{l}\text { Average spending of each of the households, in the neighbourhoods } \\
\text { of residence (in soles) }\end{array}$ \\
\hline Towns of 20,001 to 100,000 homes & $\begin{array}{l}\text { Dummy that takes the value } 1 \text { if the respondent lives in a population } \\
\text { centre of } 20,001 \text { to } 100,000 \text { homes and } 0 \text { otherwise. }\end{array}$ \\
\hline Towns of 10,001 to 20,000 homes & $\begin{array}{l}\text { Dummy that takes the value } 1 \text { if the respondent lives in a population } \\
\text { centre of } 10,001 \text { to } 20,000 \text { homes and } 0 \text { otherwise. }\end{array}$ \\
\hline Towns of 4,001 to 10,000 homes & $\begin{array}{l}\text { Dummy that takes the value } 1 \text { if the respondent lives in a population } \\
\text { centre of } 4,001 \text { to } 10,000 \text { homes and } 0 \text { otherwise. }\end{array}$ \\
\hline Towns of 401 to 4,000 homes & $\begin{array}{l}\text { Dummy that takes the value } 1 \text { if the respondent lives in a population } \\
\text { centre of } 401 \text { to } 4,000 \text { homes and } 0 \text { otherwise. }\end{array}$ \\
\hline Towns of fewer than 401 homes & $\begin{array}{l}\text { Dummy that takes the value } 1 \text { if the respondent lives in a population } \\
\text { centre of } 401 \text { homes and } 0 \text { otherwise. }\end{array}$ \\
\hline Costa Norte & $\begin{array}{l}\text { Dummy that takes the value } 1 \text { if the respondent lives in Costa Norte } \\
\text { and } 0 \text { otherwise. }\end{array}$ \\
\hline Costa Centro & $\begin{array}{l}\text { Dummy that takes the value } 1 \text { if the respondent lives in Costa Centro } \\
\text { and } 0 \text { otherwise. }\end{array}$ \\
\hline Costa Sur & $\begin{array}{l}\text { Dummy that takes the value } 1 \text { if the respondent lives in Costa Sur and } \\
0 \text { otherwise. }\end{array}$ \\
\hline Sierra Norte & $\begin{array}{l}\text { Dummy that takes the value } 1 \text { if the respondent lives in Sierra Norte } \\
\text { and } 0 \text { otherwise. }\end{array}$ \\
\hline Sierra Centro & $\begin{array}{l}\text { Dummy that takes the value } 1 \text { if the respondent lives in Sierra Centro } \\
\text { and } 0 \text { otherwise. }\end{array}$ \\
\hline Sierra Sur & $\begin{array}{l}\text { Dummy that takes the value } 1 \text { if the respondent lives in Sierra Sur and } \\
0 \text { otherwise. }\end{array}$ \\
\hline Selva & $\begin{array}{l}\text { Dummy that takes the value } 1 \text { if the respondent lives in Selva and } 0 \\
\text { otherwise. }\end{array}$ \\
\hline
\end{tabular}

SOURCE: OWN ELABORATION

Dummy that takes the value 1 if the respondent is in the lowest income quintile and 0 otherwise. Income quintiles depend on the income of a country's respondents.

Dummy that takes the value 1 if the respondent is in the second lowest income quintile and 0 otherwise. Income quintiles depend on the income of a country's respondents.

Dummy that takes the value 1 if the respondent is in the middle income quintile and 0 otherwise. Income quintiles depend on the income of a country's respondents.

Dummy that takes the value 1 if the respondent is in the second highest income quintile and 0 otherwise. Income quintiles depend on the income of a country's respondents. of residence (in soles) centre of 20,001 to 100,000 homes and 0 otherwise.

Dummy that takes the value 1 if the respondent lives in a population Dummy that takes the value 1 if the respondent lives in a population of 4,001 to 10,000 homes and 0 otherwise. Dummy that takes the value 1 if the respondent lives in a population centre of 401 homes and 0 otherwise. and 0 otherwise.

Dummy that takes the value 1 if the respondent lives in Costa Centro Dummy that takes the value 1 if the respondent lives in Costa Sur and therwise. and 0 otherwise. 